\title{
ФОРМУВАННЯ ПРОФЕСІЙНОЇ СПРЯМОВАНОСТІ МАЙБУТНІХ ЕКОЛОГІВ
}

\author{
У статті розглядається питання формування професійної спрямованості майбутніх фахівиів. На основі наукових \\ досліджень учених проаналізовано сутність поняття «спрямованість особистості» та розглянуто структуру професійної \\ спрямованості особистості. Зроблено спробу дослідити основні компоненти професійної спрямованості майбутніх \\ екологів. \\ Ключові слова: професійна спрямованість, структура, компонент, мотивація, мотив. \\ В статье рассматривается вопрос формирования профессиональной направленности будущих специалистов. На \\ основе научных исследований ученых проанализирована сущность понятия «направленность личности» и рассмотрена \\ структуру профессиональной направленности личности. Сделана попытка исследования основных компонентов \\ профессиональной направленности будущих экологов. \\ Ключевые слова: профессиональная направленность, структура, компонент, мотиваиия, мотив.
}

The article deals with the problem of formation of future specialist professional orientation. On the basis of scientific researches of famous scientists the concept of "personality orientation» is analyzed and the structure of personal professional orientation is considered. The attempt to investigate the main components of future ecologist professional orientation is done.

Key words: professional orientation, structure, component, motivation, motive.

В умовах формування нових економічних відносин, переоцінки сформованих цінностей значну увагу слід приділяти системі вищої освіти як визначального фактора оновлення та розвитку всіх сфер нашого суспільства. Зміни, що торкнулися професійної сфери на сучасному етапі, відрізняються високою динамічністю, пов'язаною з виникненням нових професій, ускладненням змісту діяльності, розпадом звичної системи цінностей, зміною стереотипів побудови професійної кар'єри і професійного розвитку. Не останню роль відіграє також економічний складник престижу тієї чи іншої професії. Отже, з одного боку професійний світ відчуває потребу у фахівцях, здатних успішно й ефективно реалізовувати себе в умовах, що змінюються, з іншого, - реальним станом професійної системи підготовки кадрів. Формування системи професійної екологічної освіти зумовлене усвідомленням незворотності екологічних змін у навколишньому середовищі і руйнуванням традиційних поглядів на модель функціонування суспільства.

Підготовка фахівців-екологів у ВНЗ передбачає здобуття відповідного обсягу теоретичних знань, зорієнтованих на майбутню професійну діяльність, практичних умінь і навичок, необхідних для діяльності в галузі охорони довкілля та раціонального природокористування. Масова підготовка фахівців у сфері екології без сформованої професійної спрямованості призводить до того, що відсоток людей, які вступають до екологічного факультету, відрізняється від відсотка, які працюють за фахом. Потреба у висококваліфікованих фахівцях ставить перед вищою школою завдання пошуку ефективних шляхів забезпечення якісної професійної підготовки майбутніх екологів.

Успіх діяльності людини в різних галуззях залежить від їі спрямованості. Саме вона визначає всю поведінку особистості, иї ставлення до себе і навколишніх. Проблемі професійної спрямованості особистості присвячено теоретичні та практичні дослідження видатних учених минулого (Аристотеля, Я. Коменського, А. Дістервега, К. Ушинського) та роботи сучасний науковців (А. Леонтьєва, С. Рубінштейна, Л. Божовича, А. Ковальова, Н. Кузьміної). Помітний внесок у дослідження цієї проблеми зробив В. Сластьонін, визначивши сутність поняття професійної спрямованості та іiі роль у структурі загальної спрямованості особистості фахівця. Велика увага приділяється змісту і структурі професійної спрямованості (Б. Теплов, А. Сейтешев, К. Платонов, I. Зимня, А. Копитов, Н. Сергєєв, П. Шавір, С. Чистякова); дослідженню ролі професійної спрямованості в процесі підготовки фахівців у ВНЗ (Л. Щербакова, К. Васильєва, А. Сейтешев, Е. Гришина, П. Гранкіна); теоретичним основам формування професійної спрямованості студентів ВН3 (В. Попова, Т. Грань, А. Городничева, А. Подобіна). Комплексний підхід до формування професійної спрямованості розглядають Я. Кофман, В. Кріволуцька, Л. Максимова, В. Шуман. Над проблемою формування професійної спрямованості через активізацію навчального процесу працюють Е. Бочарова, В. Кустова, А. Ковальов, В. Мінєєв, Н. Вяткіна, С. Юдакова, О. Назарова, В. Макова. Теоретичні моделі професійної спрямованості були запропоновані такими дослідниками як Є. Климов, А. Сейтешев, Л. Мітіна, Ю. Афонькіна, А. Підлісне, Е. Зеєр. Незважаючи на те, що професійній спрямованості особистості присвячено значну кількість наукових робіт, дослідження проблеми їі формування у майбутніх екологів залишається актуальним.

Mema cmammi - розглянути та проаналізувати структурні компоненти професійної спрямованості майбутніх екологів.

Аналізуючи літературу 3 досліджуваної проблеми, ми дійшли висновку, що професійна спрямованість розглядається як частина спрямованості особистості, iї специфічна форма.

Деякі дослідники намагалися розкрити сутність поняття «спрямованість особистості», розуміючи іiі як систему мотивів (Л. Божович), як домінуюче ставлення особистості до світу, людей, себе (В. М'ясищев, П. Якобсон); як психічні властивості, що визначають діяльність людини, іiі напрямок у 
конкретних обставинах (В. Мерлін, Н. Макаров). Л. Божович пов'язує спрямованість особистості зі стійким домінуванням певних мотивів у ієрархічній структурі мотивації і виокремлює громадську, ділову й особистісну спрямованість $[1$, с. 139]. Н. Рейнвальд посилює цю позицію тим, що вважає тип спрямованості особистості домінуючою мотивацією, за якої обирається людиною життєві цілі, ціннісні орієнтації та способи самоствердження [7, с. 134].

Протилежної думки дотримується П. Якобсон, автор уважає дискусійним твердження, що спрямованість особистості визначається через пї домінуючі мотиви, оскільки недоведеним $є$ положення про те, що кожній людині притаманні постійно домінуючі мотиви, а не їх різноманіття. На його думку, спрямованість особистості виявляється: в особливостях інтересів особистості; особливостях мети, яку людина перед собою ставить; потребах і пристрастях людини: до чого вона байдужа і що ії хвилює; установках особистості [9, с. 23 - 45].

Відмінними є погляди К. Платонова, який розуміє спрямованість у вигляді соціально зумовленої підструктури особистості, що формується шляхом виховання. Спрямованість, у свою чергу, включає такі підструктури: бажання, інтереси, схильності, ідеали, світогляд, переконання. У цих підструктурах спрямованості виявляються і відносини, і різні форми потреб [6, с. 254].

Акцентуючи увагу на різноманітті визначень спрямованості, переконуємося не тільки у своєрідності представлених теоретичних концепцій, 3 позицій яких виявляється сутність спрямованості, а й у багатоаспектності та складності цього явища.

Формування професійної спрямованості як частини загальної спрямованості особистості складний і багаторівневий процес, який залежить від багатьох чинників. До основних психологопедагогічних факторів, що впливають на формування професійної спрямованості, належать: рівень підготовки молоді, індивідуальні особливості особистості, зміст навчального матеріалу, різноманітні методи, форми й засоби навчально-виховної роботи, нетрадиційні форми навчання, якість викладання, особистість викладача та його професіоналізм, стан матеріально-технічної бази ВНЗ, готовність студентів до навчальної діяльності, їхній психологічний стан і наявність мотивації до навчання за обраною професією.

Під час визначення психолого-педагогічних чинників, що впливають на процес формування професійної спрямованості, необхідним $є$ також урахування етапів формування професійної спрямованості особистості. Л. Сподін пропонує розглянути такі періоди професійного становлення: професійної передорієнтації; професійної орієнтації (з фазами орієнтантації, вибору спеціальності та вищого закладу освіти /абітурієнта/); навчання професії (з фазами навчально-професійної адаптації, базової навчально-професійної підготовки, спеціалізації, набуття професійної кваліфікації відповідного освітньо-кваліфікаційного рівня); кваліфікованої професійної праці (з фазами соціальнопрофесійної адаптації, підвищення соціально-професійної кваліфікації, соціально-професійного удосконалення) [8, с. 20].

Професійна спрямованість, як і спрямованість особистості, включає низку компонентів. Необхідно сказати, що в педагогічній і психологічній літературі є безліч поглядів щодо складу компонентів професійної спрямованості.

На основі аналізу психолого-педагогічної літератури ми визначили, що дослідники структурних компонентів професійної спрямованості виокремлюють таке: Е. Іванова, В. Парамзін, К. Платонов розуміють як структурні компоненти професійної спрямованості інтереси, схильності, прагнення, наміри, мотиви і ціннісні орієнтації; К. Платонов, окрім того, інтерес з'ясовує як компонент, що спирається на знання і позитивні емоції, професійні ідеали, якості, що характеризують професіонала.

О. Гринько розглядає професійну спрямованість як психологічний механізм професійного розвитку особистості і професійної самосвідомості. Відтак, професійна спрямованість включає в себе ціннісно-мотиваційну сферу, самоактуалізацію і усвідомлене ставлення до себе як до майбутнього суб'єкта професійної діяльності.

На думку А. Ростунова, В. Ковальова, психологічними механізмами професійної спрямованості особистості є складна багаторівнева структура мотивів, цінностей, особистісних смислів і здібностей, що визначають професійно важливі якості. Дослідники стверджують, що оптимальний розвиток професійної спрямованості, основний зміст цього процесу полягає в підвищенні їі рівня змістовності і глибини професійного інтересу 3 урахуванням його місця в системі мотивів, що утворюють професійну спрямованість.

Е. Зеєр, 3 одного боку, співзвучний 3 позицією вищерозглянутих дослідників, 3 іншого, виокремлюючи компоненти професійної спрямованості, він розуміє ієрархію: мотиви (наміри, інтереси, схильності, ідеали); ціннісні орієнтації (сенс праці, заробітна платня, добробут, кваліфікація, кар'єра, соціальне положення); професійна позиція (ставлення до професії, установки, очікування, готовність до професійному розвитку); соціально-професійний статус.

На думку С. Сподін, основними компонентами професійної спрямованості студентів аграрних закладів є:

мотиваційний компонент (мотиви вибору професії та вищого закладу освіти, ціннісні орієнтації, нахили, інтерес до майбутньої проф. діяльності, проф. наміри); 
- когнітивний компонент (усвідомлення професійного самовизначення, розуміння суспільної значущості професії);

емоційний компонент (стійке позитивне ставлення до професії, задоволення від проф. діяльності, любов до землі (природи);

- дієво-практичний компонент (потреба в активному оволодінні спеціальними знаннями, уміннями, навичками);

оцінно-вольовий компонент (самооцінка профздібностей, прагнення підвищити іï рівень, переконання у правильному виборі професії; ставлення до труднощів своєї профдіяльності);

орієнтаційний компонент (інформованість про зміст професії, умови профдіяльності, профвимоги до особистості, потребу в кадрах) [8, с. 20].

А. Жаркєєва у своїй дисертації на матеріалі російської мови пропонує компонентно-критеріальну структуру професійної спрямованості студентів технічних ВНЗ. До структурних компонентів вона відносить: мотиваційний, когнітивний, діяльнісний та рефлексивний. А. Жаркєєва вважає, що критеріальні показники не вичерпують усього різноманіття якісних характеристик використання освітніх технологій, але в контексті проблематики дослідження є найбільш значущими [3, с. 22].

Ф. Гоноболін, В. Додонов, Ю. Забродін та Б. Сосновський, Н. Кузьміна, В. Крутецький, Б. Ломов, А. Маркова та ін. ро-зглядають професійно-педагогічну спрямованість як один із видів загальної спрямованості, до структури якої входять практичний, емоційний та когнітивний компоненти.

У процесі роботи над структурними компонентами професійної особистості нам також є близькою позиція Л. Кунц, яка вважає, що не менш важливим компонентом у структурі професійної спрямованості є емоційний компонент, оскільки в процесі вибору професії та навчанні цей компонент зумовлює формування і розвиток стійкості мотивів і професійних інтересів або їх руйнування внаслідок отримання негативних емоцій щодо професії або професійної діяльності [5, с. 84-218].

Керуючись системним i мотиваційно-смисловим підходами до дослідження спрямованості особистості, ми виокремили як структурні компоненти досліджуваного явища такі групи мотивів, які, на наш погляд, достатньою мірою ві-дображають його сутність і зміст: 1) мотиви вибору професії; 2) навчальні мотиви студентів: досягнення, пізнання, домінування, а також ступені їх задоволення; емоційне ставлення до навчальної діяльності та рівень екзаменаційної тривожності, мотиви отримання диплома та оволодіння професією; 3) система професійних уявлень, що містить два елементи: змістовний та емоційний.

У структурі професійної спрямованості майбутніх екологів ми виокремлюємо мотиви вибору професії, навчальні мотиви i систему професійних уявлень. Мотивація професійного вибору відображає усвідомлення сенсу майбутньої професії і $є$ спонукальною силою, у якій опосередкована спрямованість особистості, що здійснює вибір професійної діяльності. Ми розглядаємо мотиви професійного вибору як перший компонент професійної спрямованості особистості майбутніх екологів. Розгляд навчальних мотивів як другого компонента професійної спрямованості майбутніх екологів зумовлений тим, що в системі навчання студент є не тільки об'єктом, але й суб'єктом діяльності, навчальні мотиви відображають суспільну необхідність освоєння специфіки майбутньої професії в процесі здійснення різних форм нової провідної навчально-професійної діяльності. Третім структурним компонентом професійної спрямованості студентів, на нашу думку, є система ставлень до професії і до себе як до професіонала, який визначає кінцеву мету навчання, успішність в оволодінні професією, формування правильного і повного образу професії і себе в цій професії.

Аналіз структурних компонентів професійної спрямованості особистості, здійснений на основі зіставлення розглянутих вище позицій різних авторів, дозволив зробити такі висновки: по-перше, в дослідженнях показано, що в структурі професійної спрямованості особистості студентів наявні компоненти, які по-різному змінюються залежно від умов навчання. Сукупність зовнішніх факторів $\mathrm{i}$ спонукальних сил, утілених в мотиви, стає рушійною силою спрямованого ставлення до професії еколога; отже, найбільш важливими складниками професійної спрямованості особистості $є$ мотиви; по-друге, професійна спрямованість особистості - комплексне явище, що об'єднує всі сфери психіки і включає мотиваційний, емоційний, когнітивний, діяльнісний компоненти.

\section{Література}

1. Божович Л. И. Личность и ее формирование в детском возрасте / Л. И. Божович. - М. : Педагогика, 1986. - С. 139. 2. Гринько О. В. Развитие субъекта профессионального самоопределения в процессе обучения в школе и в вузе : автореф. дис. ... канд. псих. наук : 19.00.07 / О. В. Гринько. - Пятигорск, $2006 .-20$ с. 3. Жаркеева А. М. Формирование профессиональной направленности студентов технических вузов на материале русского языка : автореф. дис. ... канд. пед. наук: 13.00 .08 / А. М. Жаркеева. - Туркестан, 2010. 22 с. 4. Зінченко В. О. Формування професійної спрямованості студентів економічних спеціальностей на початковому етапі навчання : автореф. дис... канд. пед. наук: 13.00.04/ В. О. Зінченко. - Луганськ, $2008 .-20$ с. 5. Кунц Л. И. Особенности профессионального становления студентов / Л. И. Кунц; [под науч. ред. О. А. Белобрыкиной, О. А. Шамшиковой] // Проблемы психологии мотивации: По материалам науч.-практич. конф. - НГПУ : Новосибирск, 2005. - С. 84-218. б. Платонов К. К. Структура и развитие личности / К. К. Платонов. - М. : Наука, 1986. - 254 с. 7. Рейнвальд Н. И. Психология личности / Н. И. Рейнвальд. - М. : РУДН, 1987. - 134 с. 8. Сподін Л. А. Педагогічні умови формування професійної спрямованості особистості студентів вищих аграрних закладів освіти : автореф. дис. на здобуття наук. ступеня канд. пед. наук : 13.00 .04 / 
Л. А. Сподін. - Київ, 2001. - 20 с. 9. Якобсон П. М. Психологические проблемы мотивации поведения человека / П. М. Якобсон. - М. : ЛГПИ, 1969. - С. 23-45. 